\title{
KADAR PROTEIN DAN DAYA TERIMA SILKY PUDDING YANG DISUBSTITUSI SUSU KAMBING DAN SUSU SKIM SEBAGAI ALTERNATIF MAKANAN TAMBAHAN BALITA STUNTING
}

\author{
Syifa Rochmah ${ }^{1}$, Ahmad Yani ${ }^{2 *}$, Aminarista ${ }^{3}$ \\ 1,2,3 Sekolah Tinggi Ilmu Kesehatan Holistik \\ *Korespondensi: Jl. Veteran No.272 Ciseureuh Purwakarta, Email: ahmadyani@holisticindonesia.com
}

\begin{abstract}
ABSTRAK
Latar Belakang: Asupan protein merupakan salah satu faktor risiko stunting pada balita. Diketahui bahwa susu mampu memberikan sumbangan protein pada anak stunting sebesar 7,67 g/hari. Maka dibuatlah Silky pudding substitusi susu kambing dan susu skim yang diharapkan dapat menjadi alternatif makanan tambahan tinggi protein.

Tujuan Penelitian: Menganalisis kadar protein dan daya terima silky pudding yang disubstitusi susu kambing dan susu skim.

Metode: Penelitian eksperimental menggunakan rancangan acak lengkap satu faktor yaitu substitusi susu kambing dan susu skim. Kadar protein dan daya terima atau uji hedonik 30 orang panelis tidak terlatih dianalisis menggunakan uji Kruskal Wallis dengan uji lanjut Man Whitney.

Hasil: Terdapat perbedaan signifikan $(\mathrm{P}=0,043)$ antarakadar protein silky pudding $\mathrm{P} 1$ (substitusi susu skim) dengan silky pudding $\mathrm{P0}$ (kontrol susu kental manis) dan silky puddingP2 (substitusi susu kambing). Namun tidak terdapat perbedaan signifikan antara daya terima warna $(\mathrm{P}=0,746)$, aroma $(\mathrm{P}=0,223)$, tekstur $(\mathrm{P}=0,606)$, dan rasa $(\mathrm{P}=0,315)$ antara silky pudding $\mathrm{P} 1$ (substitusi susu skim), silky puddingP0 (kontrol susu kental manis), dan silky pudding $\mathrm{P} 2$ (substitusi susu kambing).
\end{abstract}

Simpulan: Substitusi susu kambing dan susu skim berpengaruh terhadap peningkatan kadar protein silky pudding namun tidak berpengaruh terhadap daya terima silky pudding.

Kata kunci: silky pudding, susu, protein, daya terima

ABSTRACT

Background: Protein intake is one of the risk factors for stunting in toddlers. Milk can contribute protein for stunting in children by $7.67 \mathrm{~g} /$ day. Silky pudding which is substituted goat milk and skim milk is expected to be an alternative food supplement with high protein.

Objective: Analyze protein levels and the acceptability of silky pudding substituted for goat milk and skim milk.

Method: The experimental study used a completely randomized design of one factor, the substitution of goat milk and skim milk. Protein level and acceptability or hedonic tests of 30 untrained panelists were analyzed using the Kruskal Wallis test with Man Whitney's further tests.

Result: There was a significant difference $(P=0.043)$ between the levels of silky pudding protein $P 1$ (skim milk substitution) and silky pudding protein PO (control of sweetened condensed milk) and silky pudding protein P2 (substitution of goat's milk). However, there were no significant differences between color acceptability $(P=0.746)$, flavour $(P=0.223)$, texture $(P=0.606)$, and flavor $(P=0.315$ ) between silky pudding P1 (skim milk substitution), silky pudding P0 (control of sweetened condensed milk) and silky pudding P2 (substitution of goat's milk).

Conclusion: Substitution of goat milk and skim milk has an effect on increasing silky pudding protein levels but has no effect on silky pudding acceptance.

Keywords: Silky pudding, milk, protein, acceptability

\section{PENDAHULUAN}

Stunting atau pendek merupakan gangguan pertumbuhan linier yang ditandai dengan nilai status gizi berdasarkan panjang atau tinggi badan menurut usia di bawah standar deviasi $(<-2 S D)$ jika 
dibandingkan dengan standar baku World Health Organization-MGRS (Multicentre Growth Reference Study). ${ }^{1}$ Di Indonesia, prevalensi status gizi balita pendek pada tahun 2013 yaitu sebesar 37,2\% berada diatas nilai standar yang ditetapkan WHO $(\geq 20 \%) \cdot 1,2$

Berdasarkan penelitian Hidayat dan Pinatih (2017), ${ }^{3}$ balita stunting cenderung ditemukan pada anak usia 24-59 bulan (54,3\%) dibandingkan anak berusia $0-23$ bulan (18,5\%). Tingginya prevalensi stunting pada anak usia tersebut menunjukkan bahwa stunting bersifat irreversible. Di masa depan, Stunting memiliki risiko terjadinya penyakit infeksi, penyakit degeneratif serta penurunan kemampuan kognitif dan intelektual. ${ }^{4}$

Adapun salah satu faktor yang mempengaruhi terjadinya stunting pada balita yaitu asupan protein. ${ }^{5}$ Jika asupan protein tersebut tidak segera diperbaiki maka akan berpengaruh nyata terhadap terjadinya stunting pada usia remaja dengan risiko sebesar 6,9 kali.6,7 Salah satu upaya pencegahan stunting yang dapat dilakukan secara langsung yaitu dengan pemberian makanan tambahan pada balita. ${ }^{8}$

Susu merupakan salah satu sumber protein hewani yang paling sering di konsumsi masyarakat, yang mengandung kalsium selain ikan dan makanan sumber laut lainnya. Pemberian susu skim sebanyak 200 gram perminggu selama 3 bulan meningkatkan kadar prealbumin sebesar $0,3 \pm 4,5 \mathrm{mg} / \mathrm{dl} .^{9}$ Sedangkan susu kambing etawa tidak mengandung beta-lactoglobulin (senyawa alergen) serta mampu menghambat pertumbuhan bakteri Escherichia coli. ${ }^{10}$

Silky pudding merupakan salah satu jenis cold dessert atau makanan penutup bertekstur cair atau silky yang sedang populer. Rerata bahan dasar yang digunakan dalam pembuatan silky pudding yaitu susu kental manis. Kementerian Kesehatan Republik Indonesia (2018) melarang susu kental manis diberikan kepada anak balita karena susu kental manis mengandung karbohidrat dan gula yang jauh lebih tinggi dibandingkan susu lainnya serta mengandung protein yang jauh lebih rendah. Berdasarkan hal tersebut peneliti ingin melakukan penelitian untuk mengetahui bagaimana pengaruh subtitusi susu kambing dan susu skim pada pembuatan silky pudding terhadap kandungan nilai gizi kadar protein dan daya terima sehingga dapat menghasilkan suatu produk makanan tambahan yang sesuai.

\section{METODE PENELITIAN}

Penelitian ini merupakan penelitian eksperimental menggunakan Rancangan Acak Lengkap (RAL) satu faktor (jenis susu) dengan tiga perlakuan dan tiga kali pengulangan. RAL merupakan jenis rancangan percobaan penelitian dimana perlakuan diberikan secara acak kepada seluruh unit percobaan yang bersifat homogen sehingga media atau tempat percobaan tidak memberikan pengaruh berarti pada respon yang diamati. Adapun tiga perlakuan terdiri dari P0 kelompok kontrol susu kental manis, P1 kelompok perlakuan susu skim dan P2 kelompok perlakuan susu kambing.

Pembuatan silky pudding mengacu pada standar resep silky pudding yang diperoleh dari trial and error yang mengacu pada standar resep silky pudding dengan beberapa modifikasi. Total berat silky pudding berdasarkan standar resep modifikasi diatas yaitu \pm 882 gram. Berdasarkan hasil trial error perbandingan pelarut dengan pengental (agar agar, nutrijell, dan tepung) yaitu 5:1. Adapun lama waktu pemasakan silky pudding yaitu 22 menit, 12 menit pemanasan dan 10 menit pendinginan untuk dicetak. 
Tabel 1. Formulasi Silky Pudding

\begin{tabular}{llll}
\hline \multicolumn{1}{c}{ Formula Bahan } & \multicolumn{1}{c}{$\mathrm{P0}$} & \multicolumn{1}{c}{$\mathrm{P} 1$} & \multicolumn{1}{c}{$\mathrm{P} 2$} \\
\hline Susu * & $102 \mathrm{gr}$ & $38 \mathrm{gr}$ & $51,5 \mathrm{gr}$ \\
Air kelapa & $386 \mathrm{ml}$ & $386 \mathrm{ml}$ & $386 \mathrm{ml}$ \\
Agar - agar & $2 \mathrm{gr}$ & $2 \mathrm{gr}$ & $2 \mathrm{gr}$ \\
Jeli plain & $2 \mathrm{gr}$ & $2 \mathrm{gr}$ & $2 \mathrm{gr}$ \\
Gula pasir & $40 \mathrm{gr}$ & $40 \mathrm{gr}$ & $40 \mathrm{gr}$ \\
Gula aren & $40 \mathrm{gr}$ & $40 \mathrm{gr}$ & $40 \mathrm{gr}$ \\
Tepung maizena & $6 \mathrm{gr}$ & $6 \mathrm{gr}$ & $6 \mathrm{gr}$ \\
Air & $386 \mathrm{ml}$ & $386 \mathrm{ml}$ & $386 \mathrm{ml}$ \\
\hline
\end{tabular}

Keterangan: P0 = susu kental manis, $\mathrm{P} 1$ = susu skim, $\mathrm{P} 2$ = susu kambing

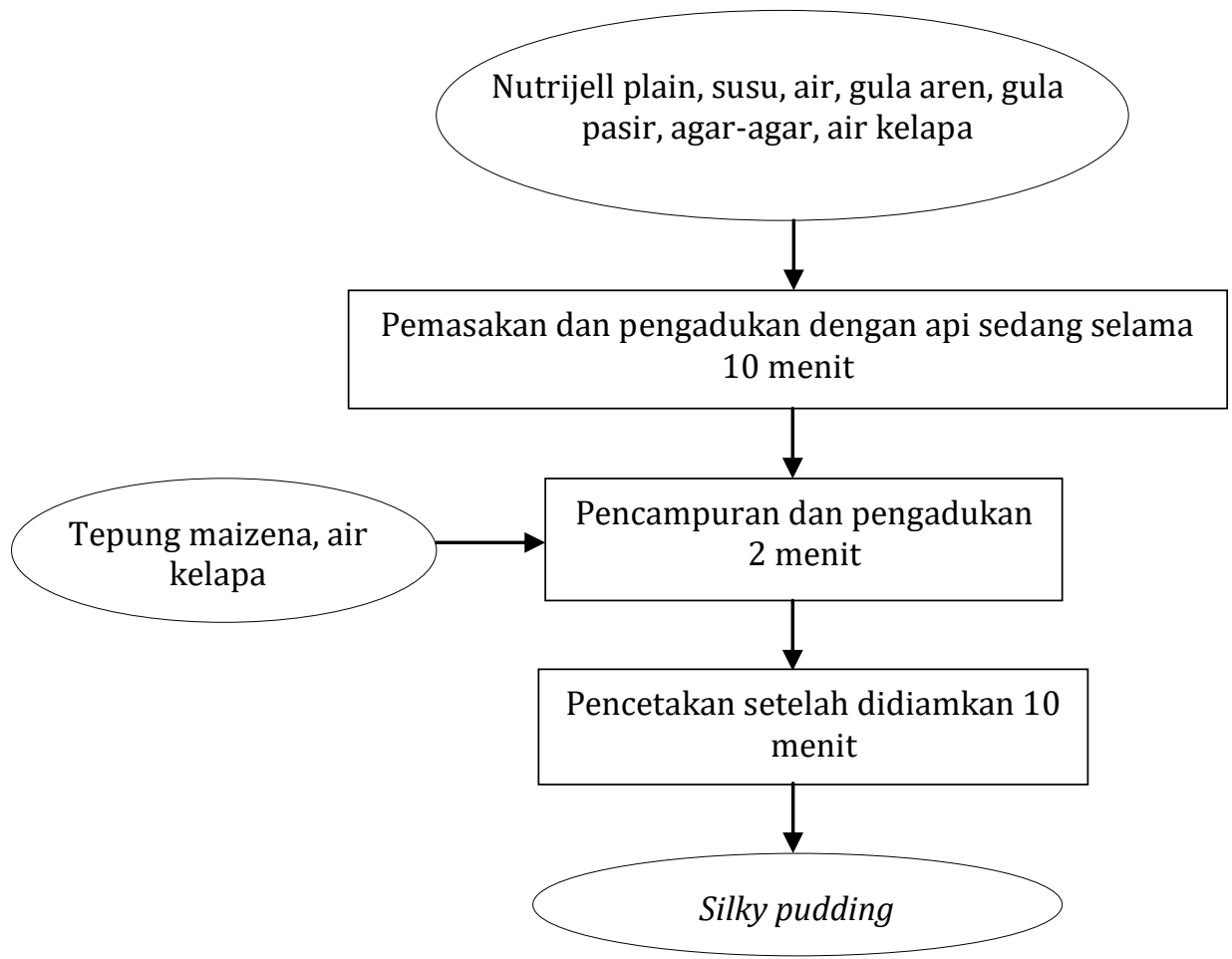

Gambar 1. Diagram Alir Pembuatan Silky Pudding

Penentuan kadar protein dilakukan dengan menggunakan metode Kjeldahl yang terdiri dari 3 tahap yaitu tahap destruksi, tahap destilasi dan tahap titrasi (Rosaini, 2015). Sedangkan pengujian organoleptik dilakukan dengan menggunakan uji hedonik yang melibatkan panelis tidak terlatih sebanyak 30 orang dari mahasiswa STIKes Holistik. Adapun skala nilai yang digunakan berupa skala numerik yang terdiri dari (1) sangat tidak suka, (2) tidak suka, (3) agak suka, (4) suka, dan (5) sangat suka.

Data hasil penelitian dianalisis menggunakan software statistik. Data hasil uji organoleptik dan kadar protein dianalisis menggunakan uji komparatif numerik tidak berpasangan. Adapun data yang dihasilkan keduanya, baik organoleptik dan kadar protein memiliki sebaran data yang tidak normal. Sehingga uji statistik yang digunakan yaitu KruskalWallis yang dilanjutkan dengan Post hoc Mann-Whitney. 


\section{HASIL PENELITIAN}

Tabel 2. Hasil Analisis Kadar Protein Silky Pudding

\begin{tabular}{ccc}
\hline Perlakuan & Rerata Kandungan Protein (\%) & Nilai p \\
\hline P0 (Susu kental manis) & $0,54 \pm 0,05^{\mathrm{b}}$ & \\
P1 (Susu skim) & $1,77 \pm 0,02^{\mathrm{a}}$ & 0,043 \\
P2 (Susu kambing) & $0,61 \pm 0,06^{\mathrm{b}}$ & \\
\hline
\end{tabular}

Keterangan: a,b berbeda nyata

Berdasarkan tabel 2, terdapat perbedaan nyata antara silky pudding P1 dengan dua perlakuan lainnya. Adapun silky pudding P0 dan P2 tidak menunjukkan perbedaan yang nyata. Silky pudding P1 dengan substitusi susu skim memiliki kadar protein tertinggi dibandingkan dengan dua perlakuan lainnya. Dari hasil analisis tersebut dapat disimpulkan bahwa terdapat pengaruh substitusi susu kambing dan susu skim pada kadar protein silky pudding.

Tabel 3. Hasil Analisis Daya Terima Silky Pudding

\begin{tabular}{ccccc}
\hline \multirow{2}{*}{ Perlakuan } & \multicolumn{4}{c}{ Rerata } \\
\cline { 2 - 5 } & Warna & Aroma & Tekstur & Rasa \\
\hline P0 & $4,03 \pm 0,41$ & $3,83 \pm 0,37$ & $4,00 \pm 0,58$ & $3,80 \pm 0,66$ \\
P1 & $4,10 \pm 0,40$ & $3,97 \pm 0,41$ & $4,07 \pm 0,45$ & $3,90 \pm 0,48$ \\
P2 & $4,10 \pm 0,30$ & $4,00 \pm 0,37$ & $4,13 \pm 0,43$ & $4,00 \pm 0,65$ \\
& $P=0,746$ & $P=0,223$ & $P=0,606$ & $P=0,315$ \\
\hline
\end{tabular}

Tabel 3 menunjukkan bahwa daya terima silky pudding P0, P1, dan P2 berdasarkan warna, aroma, tekstur, dan rasa tidak menunjukkan perbedaan nyata.Silky pudding P2 dengan substitusi susu kambing memiliki daya terima tertinggi dibandingkan dengan dua perlakuan lainnya. Dari tabel tersebut dapat disimpulkan bahwa tidak terdapat pengaruh substitusi susu kambing dan susu skim terhadap daya terima panelis akan warna, aroma, tekstur, dan rasa.

\section{PEMBAHASAN PENELITIAN}

Hasil uji Kruskal-Wallis dan MannWhitneymenunjukkan bahwa terdapat pengaruh substitusi susu kambing dan susu skim pada kadar protein silky pudding.

Kadar protein tertinggi terdapat pada silky puddingP1 (substitusi susu skim) dengan nilai rata-rata 1,77 gram per 100 gram. Sedangkan kadar protein terendah terdapat pada silky pudding $\mathrm{P0}$ (substitusi susu kental manis) dengan nilai rata-rata 0,54 gram per 100 gram. Hasil tersebut sesuai dengan penelitian Sunarlim dan Setyanto (2001),11 bahwa kandungan protein yoghurt susu kambing lebih tinggi dibandingkan dengan yoghurt susu sapi.
Sedangkan kandungan protein berdasarkan nilai gizi kemasan per-100 gram diperoleh bahwa kandungan protein susu skim lebih tinggi daripada susu kambing dan susu kental manis, namun kandungan protein susu kambing lebih tinggi dibandingkan susu kental manis. Adapun salah satu faktor yang mempengaruhi kadar protein pada bahan makanan yaitu teknik pengolahan. Semakin tinggi suhu dan semakin lama waktu pengolahan maka semakin tinggi kerusakan protein yang terjadi pada bahan pangan tersebut. ${ }^{12}$

Hasil uji Kruskal-Wallis danMannWhitney juga menunjukkan bahwa daya terima silky pudding P0, P1, dan P2 berdasarkan warna, aroma, tekstur, dan rasa tidak menunjukkan perbedaan nyata. Adapun silky pudding P2 dengan substitusi susu kambing memiliki daya terima tertinggi dibandingkan dengan dua perlakuan lainnya. Hasil tersebut sesuai dengan Sunarlim dan Setiyanto (2001),11 bahwa yoghurt susu kambing dan yoghurt susu sapi mempunyai daya terima yang sama namun panelis cenderung lebih menyukai yoghurt susu kambing.

Kadar protein tertinggi terdapat pada silky pudding P1 dengan substitusi susu 
skim. Kadar protein makanan tambahan menurut anjuran WHO yaitu 20-43g per 1000 kalori. $^{13}$ Setelah dikonversikan per 1000 kalori, kadar protein pada silky pudding pada P1 30,2 gram per 1000 kalori sudah sesuai dengan anjuran WHO. Adapun kandungan energi silky pudding pada P1 per 882 gram berdasarkan perhitungan nilai gizi kemasan yaitu 516,6 kkal. Berdasarkan berat akhir silky pudding yaitu 882 gram maka densitas energi yang diperoleh pada silky pudding P1 yaitu 0,6 kkal/gram. Apabila dibandingkan dengan anjuran dari WHO, densitas energi silky pudding P1 belum memenuhi anjuran yaitu tidak boleh kurang dari 0,8 kkal/gram.

Takaran saji silky pudding P1 substitusi susu skim 50 gram dari 882 gram (total berat silky pudding dengan energi $516,6 \mathrm{kcal}$ dan protein $14,65 \mathrm{gr}$ ) atau 50 gram dari $1,77 \%$ mengandung energi sebesar $29 \mathrm{kcal}$ dan protein sebesar 0,8 gram. Menurut Dinas Kesehatan Provinsi Jawa Barat (2010), adapun syarat makanan tambahan berdasarkan kandungan energi dan protein bagi anak balita dalam sehari yaitu 15\% total kecukupan energi (150-200 kcal) dan 16\% total kecukupan protein (4-6 gr). Jika total kecukupan energi yang diambil $175 \mathrm{kcal}$ dan total kecukupan protein 5 gr maka dapat diperoleh energi makanan tambahan sebesar $174 \mathrm{kcal}$ dan protein makanan tambahan 4,8 gr atau setara dengan 6 takaran saji (300 gram).

Pembuatan silky pudding substitusi susu skim 50 gram membutuhkan biaya sebesar 1000 rupiah. Berdasarkan hasil penelitian yang dilakukan di Bogor pada siswa kelas 4 dan 5 SD (Sekolah Dasar) dengan karakteristik sebagian besar orangtua tamatan SD $(42,5 \%)$ dan tidak tamat SD $(31,3 \%$ dan $23,8 \%)$, serta pendapatan keluarga perkapita umumnya tergolong miskin $(51,3 \%)$ dan hampir miskin (40\%) memiliki rata-rata uang jajan Rp 2.293. Adapun urutan kelompok jajanan dengan frekuensi konsumsi dalam seminggu dari tertinggi hingga terendah, yaitu makanan digoreng ( 7 kali), minuman (6,7 kali), kue (6,3 kali), jajanan sepinggan atau berat $(6,2$ kali), keringan asin (5,3 kali), dan buah (5 kali). Kelompok jajanan minuman terdiri dari es lilin dan sejenisnya, es susu, es teh, es jeruk, dan agar-agar. Silky pudding substitusi susu skim termasuk ke dalam kategori minuman (agar-agar) dengan harga 1000-1500 rupiah sudah sesuai dengan daya beli masyarakat terhadap jajanan. ${ }^{14}$

Berdasarkan hasil pengamatan selama pembuatan atau trial error, silky pudding substitusi susu skimtidak akan bertahan lama dalam suhu ruang selama 19 jam sehingga harus disimpan dalam lemari pendingin. Susu yang disimpan pada suhu kamar akan mudah rusak jika tidak mendapat perlakuan seperti pasteurisasi, pendinginan atau pembekuan, dan pemanasan..$^{15}$ Jika sudah melebihi batasan tersebut maka akan terjadi perubahan seperti tekstur yang lebih berair dan lebih lunak serta aroma dan rasa yang sedikit asam. Tanda-tanda yang dapat dikenali pada makanan yang sudah kadaluarsa yaitu makanan tersebut sudah mengalami kerusakan dan perubahan pada warna, bau, rasa, tekstur dan kekentalannya. ${ }^{16}$ Salah satu penyebabnya yaitu bakteri pembusuk pada susu seperti Micrococcus sp., Pseudomonas sp., dan Bacillus sp., yang akan menguraikan protein menjadi asam amino dan merombak lemak dengan enzim lipase sehingga susu menjadi asam dan berlendir.

\section{SIMPULAN}

1. Substitusi susu kambing dan susu skim berpengaruh terhadap peningkatan kadar protein silky pudding. Adapun kandungan protein paling tinggi terdapat pada silky pudding P1 dengan substitusi susu skim.

2. Substitusi susu kambing dan susu skim tidak berpengaruh terhadap daya terima silky pudding baik dari aroma, warna, rasa, dan tekstur. Silky pudding yang paling disukai panelis adalah silky pudding P2 dengan substitusi susu kambing etawa full cream.

Produk ini hanya dijadikan sebagai makanan tambahan dan bukan makanan pengganti. Adapun takaran saji silky pudding dalam sehari yaitu 300 gram atau setara dengan 6 cup kecil.

\section{DAFTAR PUSTAKA}

1. World Health Organization (WHO). 2010. Nutrition Landscape Information 
System (NLIS) Country Profile

Indicators: Interpretation Guide. WHO Press. Switzerland.

2. RISKESDAS. 2013. Riset Kesehatan Dasar 2013. Badan Penelitian dan Pengembangan Kesehatan Kementerian Kesehatan Republik Indonesia. Jakarta

3. Hidayat, M.S dan G.N.I. Pinatih. 2017. Prevalensi stunting pada balita di wilayah kerja Puskesmas Sidemen Karangasem. E-Jurnal Medika, 6(7), 1-5.

4. Anugraheni, H. S. dan M.I. Kartasurya. 2012. Faktor risiko kejadian stunting pada anak usia 12-36 Bulan di Kecamatan Pati, Kabupaten Pati. Tesis. Universitas Diponegoro. Semarang.

5. Wellina, W.F., M.I. Kartasurya dan M.Z. Rahfilludin. 2016. Faktor risiko stunting pada anak umur 12-24 bulan. Jurnal Gizi Indonesia. 5(1), 55-61.

6. Chastity, C. N. dan M. Shoim Dasuki. 2017. Hubungan asupan protein dengan kejadian stunting pada remaja di Sukoharjo Jawa Tengah. Skripsi. Program Studi Pendidikan Kedokteran Universitas Muhammadiyah. Surakarta.

7. Rini, I., D. Rahayuning Pangestuti dan M. Zen Rahfiludin. 2017. Pengaruh Pemberian Makanan Tambahan Pemulihan (PMT-P) terhadap perubahan status gizi balita buruk tahun 2017 (studi di Rumah Gizi Kota Semarang). Jurnal Kesehatan Masyarakat. 5(4), 698-705.

8. Khoeroh, H., D. Indriyanti. 2017. Evaluasi penatalaksanaan gizi balita stunting di wilayah kerja Puskesmas Sirampong. Unnes Journal of Public Health. 6(3), 190-195.

9. Dewi, R. dan Salimar. 2013. Pengaruh pemberian susu skim pada kadar prealbumin anak balita yang mengikuti rehabilitasi gizi rawat jalan di Puskesmas. Penelitian Gizi dan Makanan. 36(2), 157-164.

10. Erdianti, E. 2016. Aktivitas antibakteri susu kambing etawa (Capra aegagrushircus) terhadap pertumbuhan bakteri Escherichia coli. Karya Tulis Ilmiah. Studi D III Analisis Farmasi dan Makanan Akademi Putra Indonesia Malang. Malang.

11. Sunarlim, R. dan H. Setiyanto. 2001. Penggunaan berbagai tingkat kadar lemak susu kambing dan susu sapi terhadap mutu dan cita rasa yoghurt. Seminar Nasional Teknologi Peternakan dan Veteriner. Bogor.

12. Sundari, D., Almasyhuri dan A. Lamid. 2015. Pengaruh proses pemasakan terhadap komposisi zat gizi bahan pangan sumber protein. Media Litbangkes. 25(4), 235-242.

13. World Health Organization (WHO). 2012. Technical note: supplementary foods for the management of meoderate acute malnutrition in infants and children 6-59 months of age. World Health Organization. Geneva.

14. Amalia, L., O.P. Endro, dan M.R.M. Damanik. 2012. Preferensi dan dan frekuensi konsumsi makanan jajanan pada anak sekolah dasar di Kecamatan Cijeruk, Kabupaten Bogor. Jurnal Gizi dan Pangan. 7(2), 119-126.

15. Hamidah, E, I.M. Sukada dan I.B.N. Swacita. 2012. Kualitas susu kambing peranakan etawa post-thawing pada penyimpanan suhu kamar. Indonesia Medicus Veterinus. 1(3), 361-369.

16. Rustini, N.L. 2010. Aktivitas jamur penyebab busuk. Erlangga. Jakarta. 